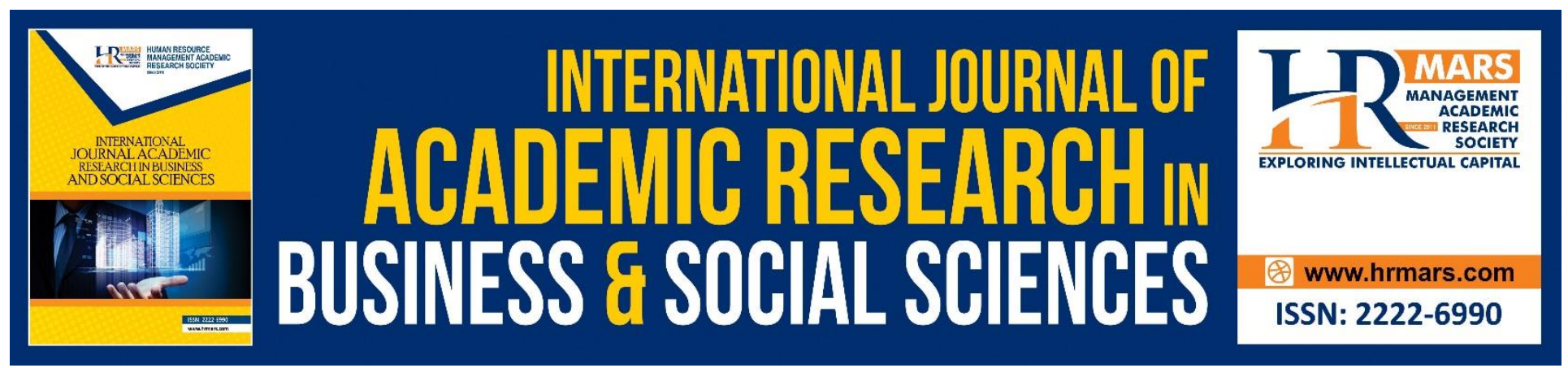

\title{
Understanding Career Commitment of Women through the Theory of Ideal Self
}

\section{Rachel Samuel A/P Samuel}

To Link this Article: http://dx.doi.org/10.6007/IJARBSS/v9-i1/5477

DOI: $\quad 10.6007 /$ IJARBSS/v9-i1/5477

Received: 14 Dec 2018, Revised: 13 Jan 2019, Accepted: 25 Jan 2019

Published Online: 06 Feb 2019

In-Text Citation: (Samuel, 2019)

To Cite this Article: Samuel, R. S. A. (2019). Understanding Career Commitment of Women through the Theory of Ideal Self. International Journal of Academic Research in Business and Social Sciences, 9(1), 738-745.

\section{Copyright: (C) 2019 The Author(s)}

Published by Human Resource Management Academic Research Society (www.hrmars.com)

This article is published under the Creative Commons Attribution (CC BY 4.0) license. Anyone may reproduce, distribute, translate and create derivative works of this article (for both commercial and non-commercial purposes), subject to full attribution to the original publication and authors. The full terms of this license may be seen at: http://creativecommons.org/licences/by/4.0/legalcode

Vol. 9, No. 1, 2019, Pg. 738 - 745

http://hrmars.com/index.php/pages/detail/IJARBSS

JOURNAL HOMEPAGE

Full Terms \& Conditions of access and use can be found at http://hrmars.com/index.php/pages/detail/publication-ethics 


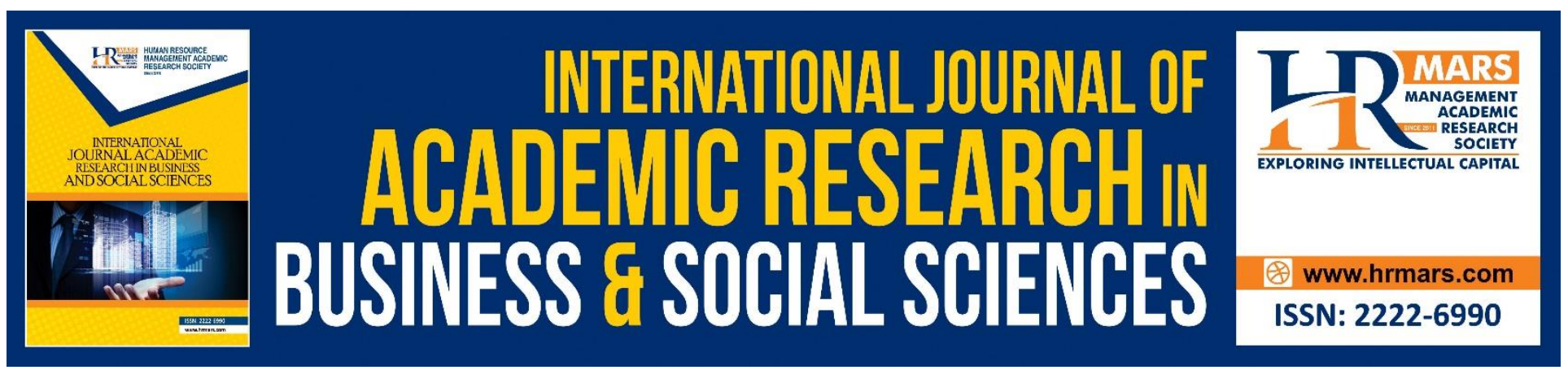

\title{
Understanding Career Commitment of Women through the Theory of Ideal Self
}

\author{
Rachel Samuel A/P Samuel \\ Universiti Teknologi MARA Cawangan Melaka, Malaysia
}

\begin{abstract}
This paper looks at the issue of participation and retention of women in the Malaysian workplace from the perspective of the personal vision of the women. A total of 117 working women responded to either online or personally administered questionnaire. The findings revealed the importance of hope and identity as elements that positively influence career commitment. Self-efficacy had no influence on women's career commitment while optimism had a negative influence. Workplaces need to look into recommendations and activities that can help enhance hope and identity of women. Further research is needed to understand how to enhance hope and identity of women so that career commitment at the workplace can be increased.
\end{abstract}

Keywords: Career Commitment

\section{Introduction}

Participation and retention of women in the workplace in Malaysia is an issue which has been given importance since 2016 (Toh \& Syahirah, 2017). The reasons for this are, first, the population of Malaysia comprises of about half women and secondly, women are becoming more educated, making up a higher proportion (55\%) in local universities. However, their participation rate in the workforce is just over 38.05\%. According to World Bank's 2017 data, Malaysia is among the lowest ranking in South East Asia when it comes to female participation in the labor force behind their neighboring countries such as Indonesia (38.29\%), Singapore (44.96\%) and Thailand (45.67\%) (Tariq, 2018). The workplace scenario in Malaysia sees more women in the workforce in their twenties. However, their numbers start to thin out once they start families causing males to outnumber the females. In middle management only a small number remain. Recommendations have been made to attract women to stay or to come back to organizations once their responsibility lessens (e.g. children are grown up, aging parents have passed on, etc). Khazanah Research Institute's (KRI) research in 2016, ranked Malaysia at 106th place out of 144 countries in terms of having the lowest number of women in the workforce ("Let's get more women", 2017). The World Bank estimates that the number of "absent women" - women who can be expected to be in the labor market given Malaysia's level of development but are not - ranges from 500,000 to 2.3 million. An IMF Report in 2016 stated that 
when women reach their full labor potential, they contribute significantly to the Gross Domestic Product (GDP) of a country (Tariq, 2018).

The former ruling government of Malaysia announced that 2018 is the year of Women Empowerment, as women are to be recognized as a pivotal resource to drive economic growth. TalentCorp Malaysia conducted a Life at Work Survey with over 360 employers and proposed Flexible Work Practices (FWP) that can be used to retain or attract women back into the workplace. Though the proposals have been adopted and implemented by a number of organizations, there are many organizations that are unwilling to put the proposals into practice due to cost constraints. The question still remains whether FWP actually attract women to stay at the workplace. Could there be other factors that actually increase the career commitment of women or enhance their retention at the workplace? Hence this paper hopes to look at the issue of career commitment of women from another perspective: the perspective of the women themselves, and not what the organizations can do to retain or attract women to be part of the workforce.

The women's perspective is based on a model built on theories of the ideal self as a personal vision (Boyatzis \& Akrivou, 2006). The ideal self can be described as one's personal vision about who the person wants to be and what she wants to accomplish in life. The ideal self is based on hope, identity, self-efficacy and optimism (Buse \& Bilimoria, 2014). Hope is defined as the feeling that something desirable is likely to happen (Boyatzis, 2008). Identity comes from strength based approaches, a set of enduring individual characteristics, which includes one's strengths, context and resources. Selfefficacy and optimism are personal resources that can help individuals achieve higher goals. Hence, personal vision is operationalized by the ideal self. The paper looks at the relationship of these dimensions with career commitment.

The personal vision has mainly been studied on women involved in Science, Technology, Engineering and Mathematics (STEM). However, this research was conducted among women from various industries who currently hold positions of middle management and above.

There are three research objectives. They are:

(i) To determine how elements of personal vision impacts career commitment;

(ii) To examine which of the elements has the highest impact on career commitment;

(iii) To suggest recommendations how workplaces can enhance career commitment of women in managerial positions.

\section{Methodology}

The research is a descriptive research conducted in a non-contrived setting using the survey method. A total of 110 working women were identified through purposive and snowball sampling techniques. The sample had to fulfill certain criteria to be chosen. First, they had to be working in positions of middle management and above, and secondly, they had to be working for more than 5 years. These criteria were set to understand women holding positions of influence at their respective workplaces and were committed to their career. Data was obtained through questionnaires which were either self-administered or sent online. The questionnaire was adopted from Buse and Bilimoria (2014). The returned questionnaires were then analyzed using SPSS version 24 . The proposed framework can be seen in Figure 1. 
INTERNATIONAL JOURNAL OF ACADEMIC RESEARCH IN BUSINESS AND SOCIAL SCIENCES

Vol. 9, No. 1, Jan, 2019, E-ISSN: 2222-6990 @ 2019 HRMARS

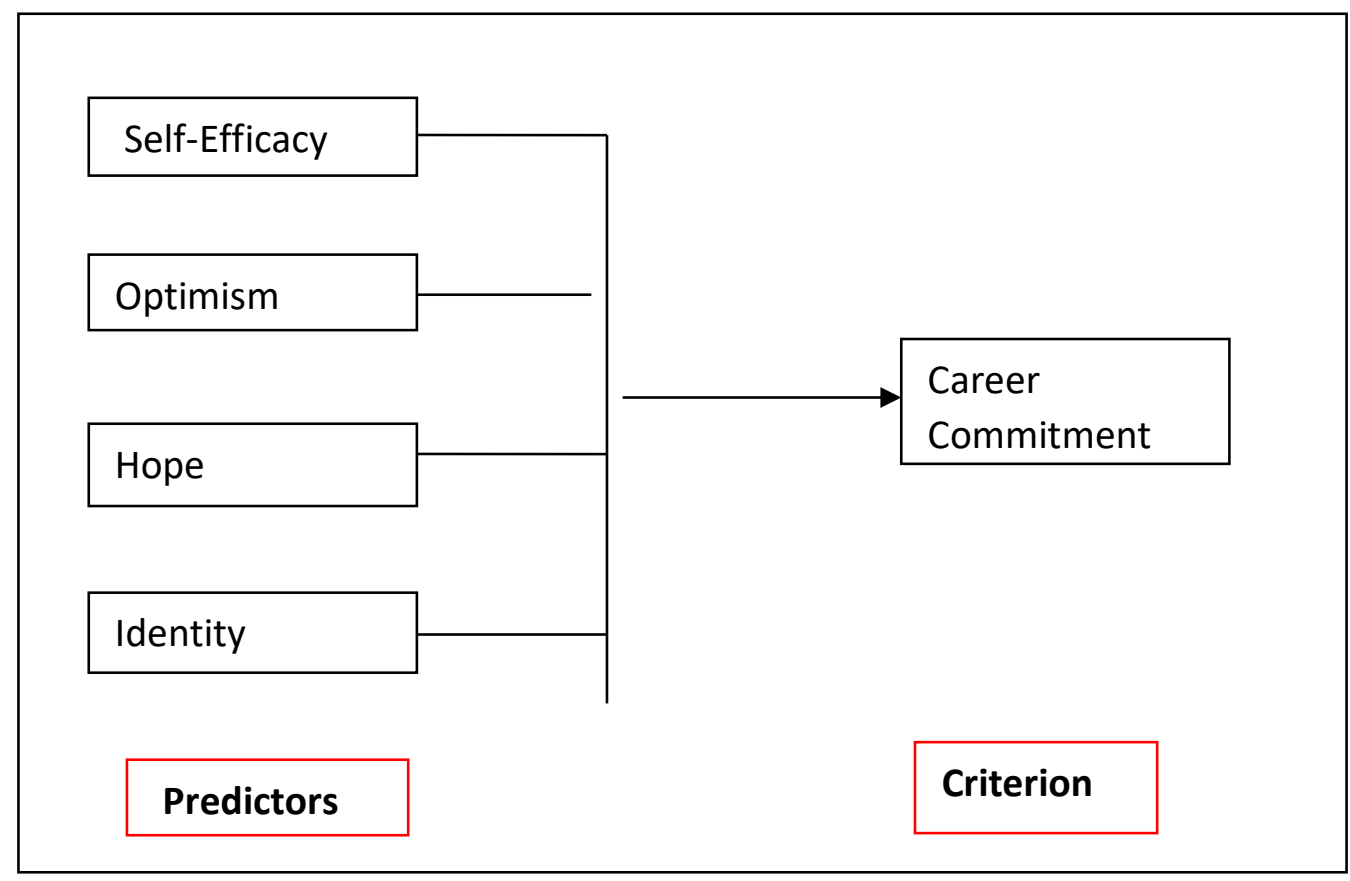

Figure 1: Research framework (Adapted from Buse \& Bilimoria, 2014)

\section{Results}

In terms of demographic characteristics, 37 years was the mean age of the respondents and they have been working for a mean period of 11 years. The highest number of women was married with children (41\%), followed by about $25 \%$ who were single with dependents. In terms of occupation, $33 \%$ held top managerial positions, followed by $23 \%$ who were professionals. They were mainly from the service industry $(27 \%)$, followed by $20 \%$ from the manufacturing industry.

The four predictors, Self-efficacy, Optimism, Hope and Identity and the criterion, Career Commitment, all had a reliability of above 0.7.; Self-efficacy 0.8, Optimism 0.76, Hope 0.81, Identity 0.8 and Career Commitment 0.84.

Self Esteem, Hope and Identity were positively correlated with Career Commitment. However, Optimism was negatively correlated with Career Commitment. Common method bias (CMB) is a concern when conducting self-reported research as it refers to variance that is attributable to the measurement method rather than to the constructs. Most researchers agree that the common method variance is a potential problem in behavioral research (Podsakoff et al., 2003). To determine if the common method for data collection impacts the measurement model, Pavlou et al. (2007) discusses examination of the correlation table of the latent variables and CMB may be present if correlations are above 0.90 . However, the analysis showed that the correlations of the study variables are all below this 0.90 standard (Table 1 ). 
INTERNATIONAL JOURNAL OF ACADEMIC RESEARCH IN BUSINESS AND SOCIAL SCIENCES

Vol. 9, No. 1, Jan, 2019, E-ISSN: 2222-6990 @ 2019 HRMARS

Table 1: Correlation Analysis

\begin{tabular}{|l|l|l|l|l|l|l|l|}
\hline & $\begin{array}{l}\text { Self } \\
\text { Esteem }\end{array}$ & Optimism & Hope & Identity & $\begin{array}{l}\text { Career } \\
\text { Commitment }\end{array}$ & Mean & SD \\
\hline Self Esteem & 1 & & & & & 3.29 & .48 \\
\hline Optimism & -.156 & 1 & & & & 1.75 & .69 \\
\hline Hope & $.369^{* *}$ & $-.241^{* *}$ & 1 & & & 6.14 & 1.13 \\
\hline Identity & $.399^{* *}$ & -.154 & $.416^{* *}$ & 1 & & 3.89 & .76 \\
\hline Career Commitment & $.420^{* *}$ & $-.335^{* *}$ & $.515^{* *}$ & $.538^{* *}$ & 1 & 3.71 & .79 \\
\hline
\end{tabular}

The regression model shows that $45 \%$ of the variance in career commitment can be explained by the independent variables. The model is statistically significant and has a good fit $(F=22.926, p<0.05)$.

Table 2: Regression Table

\begin{tabular}{|l|l|l|}
\hline Variables & Std. Coefficients (Beta) & Sig \\
\hline Self-Efficacy & 0.156 & 0.051 \\
\hline Optimism & -0.193 & 0.009 \\
\hline Hope & 0.273 & 0.001 \\
\hline Identity & 0.333 & 0.000 \\
\hline F-value & 22.926 & \\
\hline Sig. & 0.00 & \\
\hline$R^{2}$ & 0.45 & \\
\hline
\end{tabular}

Hope and Identity significantly and positively influenced Career Commitment. Optimism had a negative influence and Self-Efficacy had no influence on Career Commitment. Identity had the strongest influence on Career Commitment $(\beta=0.33, p<0.05)$.

\section{Discussion}

Hope is central to the power of the ideal self. Hope has often been conceptualized as a unidimensional construct related to a general perception that goals can and will be met. If hope is high, there will generally be higher self-efficacy and optimism as they all lead to higher career commitment. However, in this study, only hope and identity had positive effects on career commitment. The identity is the compilation of the person's enduring dispositions, which includes their unconscious motives, traits, roles taken consistently in social settings and other habits. By building the consciousness of the core identity, the individual is prepared for the image of a desired future (Boyatzis \& Akrivou, 2006).

Optimism and self-efficacy are actually related to hope and together would enhance one's career commitment. However, this was not the case in this study. Surprisingly, self-efficacy had no influence on career commitment. The stronger the perceived efficacy, the more likely are people to persist in their efforts until they succeed (Bandura, 1982). People who are relatively lower in self-efficacy are said to experience less hope and hence lower career commitment. However, this study did not discover similar findings. Optimism on the other hand had a negative influence on career commitment. 
In this study, women who have stayed in the working world in positions of middle management and above showed that only hope and identity influenced their commitment towards career. A belief in themselves and a general expectation of their career goals have helped them stay committed at the workplace. They however perceive optimism as having a negative influence. Optimism is something beyond hope, it is a belief that things will change for the better even if they seem bleak. Yet in this study, women believe that this does not help them to stay committed at the workplace. Generally women see progress in terms of gender equality at the workplace but clearly more needs to be done especially in high level jobs. Women see the workplace as a man's world so optimism is negatively related to career commitment. Women's relatively lower incomes and being paid less to do the same job as men, ultimately discourage them from being optimistic about their careers (McGregor, 2014). Self-efficacy, on the other hand, does not influence women's commitment to their careers. Selfefficacy is actually influenced by encouragement or discouragement pertaining to an individual's performance or ability to perform (Redmond, 2010). Could it be that women are not getting the encouragement that could lead to career commitment or could they be facing discouragement at the workplace?

\section{Conclusion}

In conclusion, it can be said that women's commitment to career is not fully influenced by their personal vision. Hope and identity do influence career commitment, with identity having a greater influence. However, self-efficacy does not have any influence and optimism has a negative influence. They do need hope and identity to stay at the workplace and to believe in their ability to perform. However, the barriers at the workplace might be the reasons why women do not perceive optimism or self-efficacy as important elements to enhance career commitment.

Women in the US are less optimistic than men about the future of work, according to a new survey from B2B research firm Clutch. When asked how they view their future career, more than a quarter (27\%) of working women feel worried or neutral, compared to 20 per cent of men. Gender differences correlate with other factors that impact optimism, including decision-making authority at work, according to the survey's findings. The survey suggests that men are more optimistic about the future because they are more likely to have decision-making authority in their job. Higher levels of authority correlate with higher levels of optimism (Franklin, 2018).

FWP can help to a certain extent but without the removal of the barriers at the workplace, women will not feel that they can contribute greatly to the effectiveness of the workplace.

Women in the Workplace 2017, a study conducted by Leanln.Org and McKinsey, looked more deeply at why there are fewer women in top positions in many organizations. Their study drew on data from 222 companies employing more than 12 million people, as well as on a survey of over 70,000 employees and a series of qualitative interviews. They found, perhaps, unsurprisingly, that women are less optimistic about their prospects. They are less likely than men to aspire to be top executives. And even the women who aspire to be top executives are significantly less likely to think they will become better than men with the same aspiration. 
Future research should look into how barriers impact women's commitment to their career. It would be useful to understand if personal vision of women can be enhanced if barriers at the workplace are removed. FWP can help to a certain extent but if barriers at the workplace still exist, women will still not be a major contributor to the workplace. The Malaysian government has also implemented Affirmative Action to improve women's participation at the workplace, however, if barriers at the workplace still remain, this effort would prove futile.

\section{Acknowledgement}

The authors would like to acknowledge and thank IRMI, Universiti Teknologi MARA Malaysia as well as the Ministry of Higher learning Malaysia for the Fundamental Research Grant Scheme (FRGS) funding to carry out this research (600-IRMI/FRGS 5/3 (36/2016)

\section{Corresponding Author}

Rachel Samuel A/P Samuel

Universiti Teknologi MARA Cawangan Melaka

Malaysia

Email: rachelsam@bdrmelaka.uitm.edu.my

\section{References}

Bandura, A. (1982). Self-efficacy Mechanism in Human Agency. American Psychologist, 37(2), 122-174. http://dx.doi.org/10.1037/0003-066X.37.2.122

Boyatzis, R.E. (2008). Leadership Development from a Complexity Perspective. Consultant Psychology Journal, 60, 298-313. http://dx.doi.org/10.1037/1065-9293.60.4.298

Boyatzis, R.E., \& Akrivou, K. (2006). The Ideal Self as the Driver of Intentional Change. Journal of Management Development, 25(7), 624-642. http://dx.doi.org/10.1108/02621710.61.0678.454

Buse, K., \& Bilimoria, D. (2014). Women Persisting in the Engineering Profession: The Role of the Ideal Self and Engagement. In D. Bilimoria, L. Lord, \& M. Marinelli (Eds.), Women in STEM Careers: International Perspectives on Increasing Workforce Participation, Advancement and Leadership (pp. 16-38). London: Edward Elgar.

Franklin, N. (2018, June 5). Women are Less Optimistic than Men about the Future of Work. Workplace Insight. Retrieved from https://workplaceinsight.net.

Let's Get More Women into the Workforce. (2017, March 17). New Straits Times Online. Retrieved from https://www.nst.com.my.

McGregor, J. (2014). The Human Rights Framework and Equal pay for Low Paid Female Careers in New Zealand. New Zealand Journal for Employment Relations, 38(2), 4-16.

Podsakoff, P.M., Mackenzie, S.B., Lee, J.Y., \&. Podsakoff, N. (2003). Common Method Bias in Behavioral Research: A Critical Review of the Literature and Recommended Remedies. Journal of Applied Psychology, 5, 879-903. http://dx.doi.org/10.1037/00219010.88.5.879

Pavlou, P., Liang, H., \& Xue, Y. (2007). Understanding and Mitigating Uncertainty in Online Exchange Relationships: A Principal-Agent Perspective. MIS Q, 31, 105-136. 
INTERNATIONAL JOURNAL OF ACADEMIC RESEARCH IN BUSINESS AND SOCIAL SCIENCES

Vol. 9, No. 1, Jan, 2019, E-ISSN: 2222-6990 @ 2019 HRMARS

Redmond, B.F. (2010). Self-Efficacy Theory: Do I Think That I Can Succeed in My Work? Work Attitudes and Motivation. Retrieved from https://cms.psu.edu.

Tariq, Q. (2018, June 25). Righting the balance. Star 2 Online. Retrieved from https://www.star2.com.

Toh, B. \& Jaafar, S. S. (2017, November 27). Focus on Retention of Women in the

Workforce.

The Edge Markets. Retrieved www.theedgemarkets.com. 